\title{
BANKING SYSTEM: THE STATE RUSHES TO RESCUE1
}

\author{
M.Khromov
}

The volume of state support to the banking sector totaled $R b 1.7$ trillion in 2015. In particular, recapitalization of major banks has exceeded Rb 1.1 trillion of which major state banks received $R b 800 \mathrm{bn}$. These measures maintained capital adequacy at the required level ${ }^{1}$.

In 2014-2015, government financial support to the banking sector included growth of its capital and implementation of procedures aimed at weak banks resolution. Moreover, guarantee of continuous operation of deposit insurance system required additional financial investment as the Deposit Insurance Agency (DIA) was already to run out of assets in mid-summer of $2015^{2}$. Consequently, missing funds needed to pay to the depositors of closed banks had to be provided as a loan by the Bank of Russia extended to the Deposit Insurance Agency. What was the total amount of funds provided by the state to the banking sector? Let us make an in-depth analysis of aforementioned categories of support provided to the banking sector.

1. Change of conditions for state banks recapitalization during 2008-2009

In the course of 2008-2010 crisis, the banking sector also received significant amounts of public funds. In particular, in accordance with the Federal Law No 173-FZ "On Additional Measures for Supporting the Financial System of the Russian Federation" the Bank of Russia extended to Sberbank subordinated credits totaling to $\mathrm{Rb} 500 \mathrm{bn}$. A number of major banks obtained subordinated credits from Vnesheconombank at the expense of assets from the National Wealth Fund (NWF) placed on depo accounts with Vnesheconombank. Initial loan periods were to terminate in December 2019. This means that already in 2015 loan repayment was to commence and discounted in the loan recipient's capital ${ }^{3}$.

In order to avert this, in 2014 amendments were introduced into the Federal Law No 173-FZ, which upon government decision allowed to allocate the NWF funds to purchase preference shares by the banks, which cleared due payments on subordinated credits. To banks, this procedure signified not only stabilization of the capital base but also improvement of the capital quality. Instead of Tier 2 capital where usually subordinated credits are included, banks received Tier 1 capital. At the same time, by a provision these shares were exempt from mandatory dividend payments. In other words, the cost of drawn capital decreased for the banks. Moreover, growth of Tier 1 capital

1 This paper was originally published in Online Monitoring of Russia's Economic Outlook No.3(21).

2 See: Michail Khromov. The Insurance System Does Not Cope with Bank Sanation. OMES № 9, June 2015.

3 The amount of subordinated credit included in the calculation of bank capital evenly decreases over last five years of the loan period. Thus, commencing with 2015, capital of banks - recipients of subordinated credits in accordance with Federal Law 173 FZ was to decline gradually by $5 \%$ of the credit amount per quarter. 
expanded banks' options to obtain new subordinated credits, whose inclusion in the banks' capital is limited by the volume of Tier 1 capital.

As a result, since late 2014 such decisions were taken regarding three major banks: Bank VTB, Rosselkhozbank, and Gazprombank. Total amount of loans converted into preference shares came to Rb 279bn. Besides, VTB and Gazprombank since December 2014 obtained new subordinated loans from the assets of NWF totaling to Rb 164 bn (Rb 124bn for VTB and Rb 38bn for Gazprombank).

Special situation has come about Sberbank. First, Sberbank obtained subordinated loan totaling to $\mathrm{Rb} 500 \mathrm{bn}$ directly from its main shareholder - the Bank of Russia. In 2010, amid recovery growth of both the Russian economy and the lending market, Sberbank management considered this loan excessively expensive (initial rate was $8 \%$ per annum) that is why a part thereof in the amount of $\mathrm{Rb} 200 \mathrm{bn}$ Sberbank returned to the Bank of Russia prior to maturity.

In summer 2010, the Federal Law No 173-FZ got an amendment ${ }^{1}$, which reduced the cost of the Sberbank subordinated loan to $6.5 \%$ per annum. In June 2014, Sberbank obtained $\$ 200 \mathrm{bn}$ in accordance with the same law. According to the effective to that date version of $173-\mathrm{FZ}$ the interest rate amounted to $6.5 \%$.

In July 2014, the Federal Law No 173-FZ received amendments, which envisage extension of subordinated loans period granted to Sberbank to 50 years. In autumn 2014, amendments were introduced into Regulation 395-P ("On the Methodology for Determining the Amount of Own Funds (Capital) of Credit Institutions"), which allowed to include in the capital subordinated credits extended in accordance with new version of the Federal Law No $173 \mathrm{FZ}$.

Starting from reporting date 1 April 2015, subordinated loans extended to Sberbank in accordance with the Federal Law No 173-FZ were included in the amount of $\mathrm{Rb} 500 \mathrm{bn}$, which means that they were fully rescheduled for a period of 50 years.

Consequently, amendments to the law introduced during 2014-2015 allowed Sberbank to increase its capital starting from 1 April 2015 by a minimum of $\mathrm{Rb} 215 \mathrm{bn}$ ( $\mathrm{Rb} 200 \mathrm{bn}$ - repeated loan tranche drawn in June 2014, $\mathrm{Rb}$ $15 \mathrm{bn}$ - termination of depreciation to the tune of $\mathrm{Rb} 300 \mathrm{bn}$ due to extended period of subordinated loan).

Thus, since mid-2014, major state banks were able to improve the quality of their capital to the tune of $\mathrm{Rb} 779 \mathrm{bn}$ avoiding subordinated loans depreciation and additionally received Rb 164bn from the NWF assets.

2. State support of the banking sector with participation of the public corporation Deposit Insurance Agency.

In December 2014, DIA received additional contribution from the RF Government - special issuance of the federal loan bonds (FLB) totaling to $\mathrm{Rb} 1$ trillion for further allocation in the capital of commercial banks. After that, a list of banks was approved, which were eligible after meeting certain conditions for recapitalization from the DIA funds. One of the preconditions of recapitalization was contribution limit capped at $25 \%$ of the own funds of the recipient bank as of 1 January 2015. Because total capital of the eligible banks amounted to $\mathrm{Rb} 3.454$ trillion (43.6\% of the total capital of the banking sector) prospective volume of recapitalization was initially limited to $\mathrm{Rb} 864 \mathrm{bn}$.

1 Federal Law of 27.07.2010 № 206-FZ. 
During 2015, 25 banks were eligible for recapitalization. As a result, they received from DIA contributions to their capital to the tune of $\mathrm{Rb} 803 \mathrm{bn}$. At the same time, recapitalization of Bank VTB and 'Otkrytie' was carried out taking into account limits imposed on their subsidiary banks, which also were on the list.

\section{Weak banks resolution.}

2015 set record regarding the number of cancelled licenses: 93 credit institutions lost the right to carry out their activity. Nevertheless, apart from that, the financial restructuring procedure was launched against certain banks under the DIA supervision. In 2015, financial restructuring procedure was launched against 14 banks with total funds around $\mathrm{Rb} 900 \mathrm{bn}^{1}$. Total number of banks subject to financial restructuring hit 28 in early 2016. Aggregate volume of financial support to these banks as of early 2016 totaled Rb 1.2 trillion, of which $\mathrm{Rb} 491 \mathrm{bn}$ was extended in 2015. The Bank of Russia is the main source of this financial support. It allocated Rb1.159 trillion ( $R b$ 488bn in 2015). The DIA provided the remaining funds at the expense of asset contribution extended by the Russian Federation.

\section{Financing payment to depositors of banks stripped of licenses.}

Out of 93 credit institutions, which lost their licenses in 2015, 77 credit institutions participated in deposit insurance system. Aggregate volume of payments in 2015 carried out by the Deposit Insurance Agency to the bank depositors on the occurrence of insurance events totaled $\mathrm{Rb} 369 \mathrm{bn}$, additional $\mathrm{Rb} 64 \mathrm{bn} \mathrm{DIA}$ paid in January 2016. At the same time, as of early 2015 according to the DIA data, the Mandatory Insurance Fund totaled Rb 69bn. Over 9 months of 2015, contributions to the Fund came to $\mathrm{Rb} 82 \mathrm{bn}$. Final data for a year was unavailable as of the date of this review, however, according to our estimates, contributions did not exceed Rb 100bn. Therefore, the Deposit Insurance Agency had to receive at least $\mathrm{Rb} 200 \mathrm{bn}$ from the alternative sources to able to pay depositors in 2015. It is known that in August 2015, the right for unsecured loan application to Bank of Russia to the tune of Rb $100 \mathrm{bn}$ for a period of 5 years was approved in the event the liquid assets of the Fund fall below $\mathrm{Rb} 40 \mathrm{bn}$.

Table 1

STATE SUPPORT MEASURES FOR BANKING SECTOR IN 2015 ALONG CERTAIN GROUPS OF BANKS, RB BN

\begin{tabular}{|c|c|c|c|c|c|c|}
\hline & \multicolumn{2}{|c|}{$\begin{array}{l}\text { Rescheduling of } \\
2008 \text { support }\end{array}$} & \multirow{2}{*}{ 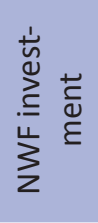 } & \multirow{2}{*}{ 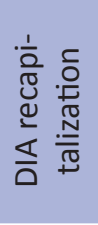 } & \multirow{2}{*}{ 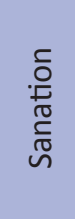 } & \multirow{2}{*}{ 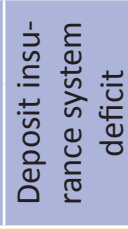 } \\
\hline & 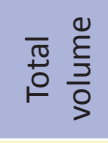 & 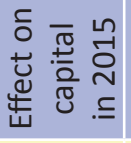 & & & & \\
\hline Sberbank & 500 & 100 & & & & \\
\hline VTB group & 214 & 43 & 38 & 307 & & \\
\hline Gazprombank & 40 & 8 & 126 & 126 & & \\
\hline Rosselkhozbank & 25 & 5 & & 69 & & \\
\hline $\begin{array}{l}\text { Other bank recapi- } \\
\text { talized by DIA }\end{array}$ & & & & 301 & & \\
\hline $\begin{array}{l}\text { Banks subject to finan- } \\
\text { cial restructuring }\end{array}$ & & & & & 491 & \\
\hline Banks with lost licenses & & & & & & 200 \\
\hline Total & 779 & 156 & 164 & 803 & 491 & 200 \\
\hline
\end{tabular}

1 As of latest reporting date prior to commencement of bank resolution. 
In view of this, we estimate aggregate volume of direct support provided to the banking sector in 2015 minimum at $\mathrm{Rb} 1.7$ trillion (Table 1, columns 3-6). Moreover, additional effect for the capital of major banks totaled Rb 156bn due to change of recapitalization conditions within 2008 law. In 2015, aggregate capital growth of the banking sector hit $\mathrm{Rb} 1,080 \mathrm{bn}$. At the same time, bank capital growth due to new contributions and reschedule of 2008-2009 loans came to $\mathrm{Rb} 1,123 \mathrm{bn}$ (Table 1, columns $2-4$ ), Rb $822 \mathrm{bn}$ of which were received by major banks. In other words, all positive increment of the banking sector capital in 2015 was secured exclusively thanks to state support measures.

These measures, to a significant degree, maintained capital adequacy ratio within required limits. For example, the value of capital adequacy ratio of the banking sector as a whole without the implementation of aforementioned measures of recapitalization as of 1 January 2016 could be at $11.1 \%$ instead of $12.7 \%$ is reality. Regarding capital adequacy, state banks have gained still more: 2 p.p. (Table 2). Moreover, a number of banks would have failed to meet capital adequacy requirement without drawing additional funds. This is true of Bank VTB and a number of private banks such as MDM, Rossyisky capital, Binbank and some other.

Table 2

\section{EFFECT OF MEASURES OF RECAPITALIZATION OF BANKING SECTOR ON CAPITAL ADEQUACY}

\begin{tabular}{|l|c|c|}
\hline B1 os af 1.01.2016 & $\begin{array}{c}\text { H1 without measures } \\
\text { of recapitalization }\end{array}$ \\
\hline Banking system & 12.7 & 11.1 \\
\hline State banks & 12.5 & 10.5 \\
\hline Sberbank & 11.9 & 11.4 \\
\hline VTB group & 12.4 & 8.7 \\
\hline Gazprombank & 13.6 & 10.2 \\
\hline Rosselkhozbank & 16.6 & 13.7 \\
\hline Other banks & 13.0 & 11.9 \\
\hline
\end{tabular}

